\title{
Kritik Hadis Zakaria Ouzon
}

\author{
Bahrudin Zamawi \\ Institut Pesantren KH Abdul Chalim Mojokerto \\ zamawi@ikhac.ac.id
}

\begin{abstract}
;
Hadis has strength authority as Islamic law. It's function is the explanatory of the Qur'an and otherwise. The significance of the hadis requires its protecting and conserving by codification. Muslim scholars had collected thousands of hadis in many books that well-known as The Nine Primary Book of Hadis (Kutūb al-Tis'ah). One of them, Sahịh al-Bukharri, was claimed as the most authentic book, because it is contain the only authentic (sahịh) hadis. Moreover Sahịh al-Bukhari had important position as the source of Islamic law right below Quran. But the popularity of Sahịh al-Bukhäri was underestimated by Zakaria Ouzon, the scholar who criticized works of many muslim scholars, one of them is Sahịh al-Bukhäri. He claimed that hadis collected in Sahịh al-Bukhäri was authentic (sahịh) and could be used as hujjah. He argued that some hadis in Sahịh al-Bukhäri must be doubted as authentic, because of its contrary to Quran and Hadis Mutawwatir textualy. Zakaria used comparative theory to proof the authenticity of hadis by comparing hadis in Sahịh al-Bukhäri with Quran and Hadis Mutawwatir. One of hadis' that criticized by Zakaria was hadis about angels cursed wife who denied the husband's invitation for having sex. He stated that this hadis was contrary to Quran and the principles of Islamic doctrine which respect the dignity and honor of the women. Therefor that hadis must be doubted its authenticity. Zakaria's thoughts about authenticity of hadis in Sahịh al-Bukhāri was stated in his work, Jināyat al-Bukhäri, probably, has the same tendency with most contemporary muslim scholars who tried to reconstruct the interpretation of hadis which literally contraty to Quran, hadis mutawwatir, and Islamic doctrines. But Zakaria seems to criticize loudly with doubting the authenticity of hadis in Sahịh al-Bukhäri.
\end{abstract}

Key Word: Critic hadith, Zakaria Ouzon

\section{Abstrak;}

Hadis memiliki otoritas kuat sebagai sumber hokum Islam. Hadis berfungsi sebagai penjelas al-Qur'an, begitu juga sebaliknya. Pentingnya hadis dalam ajaran Islam menuntut agar ia selalu terjaga dan dilestarikan melalui kodifikasi. Proses kodifikasi yang dilakukan oleh para sarjana muslim menghasilkan banyak kitab primer hadis yang terkenal dengan sebutan kutūb al-tis'ah, yang salah satu diantaranyya, yakni sahịh albukhāri, diklaim sebagai kitab hadis paling sahih dan menempati posisi tepat di bawah Alquran sebagai sumber hokum. Ini dikarenakan sahịh al-bukhäri memuat hadis-hadis yang berkualitas sahih saja. Namun ketenaran sahịh al-bukhäri dipandang miring oleh Zakaria Ouzon, seorang pemikir yang banyak mengkritik karya-karya Sarjana Muslim, salah satunya adalah sahịh al-bukhäri. Dalam karyanya yang berjudul Jinayăt alBUkhäri, Zakaria menjelaskan bahwa tidak seluruh hadis yang terhimpun dalam sahịh al-bukhāri berstatus sahih dan bisa dijadikan hujjah. Ia beralasan bahwa terdapat beberapa hadis yang perlu diragukan autentisitasnya karena bertentang dengan Alquran dan hadis mutawwatir secara tekstual. Untuk menguji autentisitas hadis Zakaria 
menggunakan teknik perbandingan, yakni membandingkan hadis dengan Alquran dan hadis yang mutawwatir. Salah satu hadis yang mendapat kritik dari Zakaria adalah hadis tentang istri yang mendapat laknat dari malaikat karena enggan diajak berhubungan dengan suaminya. Menurutnya hadis ini jelas bertentangan dengan Alquran dan ajaran Islam yang menjunjung tinggi harkat dan martabat perempuan, sehingga perlu diragukan autentisitasnya. Pemikiran Zakaria Ouzon yang tertuang dalam kitabnya jināyat al-Bukhāri agaknya memiliki kecenderungan yang sama dengan sarjana muslim lain yang mencoba merekonstruksi makna hadis yang secara tekstual bertentangan dengan Alquran, hadis mutawwatir, dan ajaran Islam. Namun Zakaria nampak lebih keras mengkritik dengan meragukan autentisitas hadis-hadis riwayat Bukhari.

\section{Kata Kunci: Kritik Hadis, Zakaria Ouzon}

\section{Pendahuluan}

Studi teks agama, yang dalam hal ini agama Islam, selalu menarik untuk dikaji. Baik Alquran maupun hadis selalu mengalami perkembangan pemaknaan dan pemahaman agar selalu relevan dengan zaman. Hal ini didasarkan pada bahwa agama Islam adalah agama yang risalahnya sesuai dengan segala waktu dan tempat. ${ }^{1}$ Masyarakat yang memiliki kebudayaan yang heterogen menuntut adanya pemaknaan ulang terhadap teks-teks agama agar bisa diaplikasikan dan sesuai dengan situasi dan kondisi masyarakat serta sebagai jawaban atas permasalahan kehidupan sehari-hari. ${ }^{2}$

Studi terhadap teks-teks agama pada dasarnya telah dilakukan semenjak masa nabi Muhammad. Pada masa ini peran reader dalam memahami teks agama, baik Alquran maupun hadis kurang begitu terlihat, karena jika seseorang tidak memahami tentang suatu hal, maka nabi adalah rujukan utama untuk dapat memahami teks tersebut. ${ }^{3}$ Permasalahan muncul ketika nabi wafat. Siapa yang akan menjadi rujukan dalam menjelaskan teks agama baik Alquran maupun hadis. Lantas muncullah inisiatif untuk melakukan usaha dalam memahami teks agama tanpa dampingan nabi. Usaha ini dikenal dengan istilah ijtihād. ${ }^{4}$

Pada generasi selanjutnya kegiatan ijtihad ini mengalami perkembangan yang cukup pesat. Terbukti dengan berkembangnya beberapa disiplin ilmu, seperti hukum, hadis kalam, dan cabang ilmu lainnya serta usaha untuk mengkodifikasi hasil ijtihad para ahli dalam bidang tersebut. Kitab-kitab hasil ijtihad para ahli ini kemudian menjadi sumber rujukan utama dalam menggali hukum hingga saat ini.

\footnotetext{
${ }^{1}$ Syuhudi Ismail, Hadis Nabi yang Tekstual dan Kontekstual, (Jakarta: Bulan Bintang, 1994), 5.

${ }^{2}$ Ibid. 8.

${ }^{3}$ Semasa nabi masih hidup, para sahabat menimba ilmu secara langsung kepada beliau. Para sahabat secara bergiliranmendatangi majelis nabi untuk mendapatkan petunjuk baik ilmu dunia maupun ilmu akhirat. Bahkan ada beberapa kabilah yang datang dari tempat jauh untuk mengikuti majelis nabi. Lihat Musthafa al-Siba'i, al-Hadis sebagai Sumber Hukum: Kedudukan al-Sunnah dalam Pembinaan Hukum Islam, terj. Dja'far Abd. Muhith, (Bandung: Diponegoro, 1993), hlm. 87- 88.

${ }^{4}$ Ijtihad sudah dikenal dan dilakukan pada masa sahabat. Hal ini berdasarkan hadis nabi:

$$
\text { عليكم بسنتي و سنّة الخلفاء الرّّاشدين من بعد }
$$

Kata sunnah yang kedua dalam hadis tersebut dipahami sebagai ijtihad. Lihat al-Siba'i, al-Hadis sebagai Sumber Hukum, 70.
} 
Dalam bidang hadis, dalam catatan sejarah beberapa sahabat nabi sudah melakukan usaha untuk menuliskan hadis di berbagai macam media yang ada. Disebutkan bahwa catatan-catatan yang berisi hadis yang tertua adalah catatan milik 'Abd Allah bin 'Amr bin 'Āṣ yang dikenal dengan sebutan Șậifah al-Sädiqah.5 Meski pada masa sahabat sudah dimulai penulisan hadis, namun kegiatan penulisan hadis mengalami stagnasi hingga beberapa tahun lamanya. Hingga pada masa Khalifah 'Umar bin Abd' al-Azizz muncul gerakan yang signifikan dalam kodifikasi hadis. Usaha kodifikasi ini adalah sebagai upaya untuk menyelamatkan hadis agar tidak sampai hilang karena hadis merupakan sumber hukum Islam setelah Alquran. Salah satu kitab yang sampai saat ini menjadi rujukan utama dalam bidang hadis adalah Sạhị̣ alBukhāri. Kitab ini merupakan rujukan utama dalam menggali hukum ${ }^{6}$ dan mencari hadis-hadis yang otentik. ${ }^{7}$

Tetapi nama masyhur kitab Șahịh al-Bukhäri ternyata dipahami secara berbeda oleh beberapa orang. Salah satunya adalah Zakaria Ouzon yang memandang bahwa hadis-hadis yang terdapat dalam kitab Șạịh al-Bukhāri tidak seharusnya diterima dan dipahami secara normatif sebagai wahyu. Karena banyak hadis-hadis yang terdapat dalam kitab tersebut yang bertentangan dengan Alquran dan sunnah lain yang lebih tinggi derajatnya. Tentunya hadis-hadis yang seperti ini perlu dicurigai keotentikannya, karena bertentangan dengan Alquran yang qat' 'i al-wurüd.

Berdasarkan hal tersebut, Zakaria menolak pensakralan Sạhịh al-Bukhāri sebagai kitab yang memuat hadis-hadis yang otentik. Untuk menguji dan meneliti hadis-hadis yang tidak otentik dalam kitab Sahịh al-Bukhāri Zakaria menulis sebuah karya yang berjudul Jināyat al-Bukhāri. Kitab karya Zakaria Ouzon ini memuat hadishadis yang tidak otentik dan perlu dikaji ulang maknanya dalam kitab Sahịh alBukhäri.

Sikap skeptis yang ditampakkan oleh Zakaria Ouzon terhadap Șahịh al-Bukhāri dalam Jināyat-nya kitab sangat menarik untuk dikaji. Yang menjadi perhatian penulis adalah metode yang digunakan Zakaria untuk menggugurkan beberapa hadis yang ia kritik sebagai tidak autentik dalam Șạị̂h al-Bukhāri.

Penelitian ini menggunakan metode library research, yakni penelitian terhadap teks yang merupakan obyek penelitian. Adapaun sumber primer dalam penelitian ini adalah buku Jināyat al-Bukhäri karya Zakaria Ouzon dan sumber data sekunder adalah literatur-literatur lain yang mendukung penelitian ini. Hasil penelitian ini akan disajikan secara deskriptif-analitis. Obyek penelitian ini akan dipaparkan secara deskriptif dan seakurat mungkin untuk menghindari misunderstanding. Data-data yang didapat dalam penellitian ini kemudian akan dianalisis, baik dari sumber data primer mapun sekunder.

\section{Biografi Zakaria Ouzon}

\footnotetext{
${ }^{5}$ Nabia Abbott, Studies in Arabic Literary Papyri: Qur'anic Commentary and Tradition. Vol. II, (Chicago: The University of Chicago Press, 1967), 7

${ }^{6}$ Kaitannya dengan hadis yang menjadi sumber hukum Islam yang kedua.

${ }^{7}$ Karena klaim ahli hadis yang menyatakan bahwa Șahịh al-Bukhäri memuat hadis-hadis yang otentik. Lihat Indal Abror, Kitab al-Șạịh al-Bukhāri, dalam Studi Kitab Hadis, (Yogyakarta: Teras, 2003), 44.
} 
Zakaria Ouzon merupakan tokoh yang cukup aktif dalam dunia tulis menulis. Hal ini terbukti dari trilogi kitab Jinăyat-nya ${ }^{8}$ yang muncul di publik. Selain itu ia juga menulis beberapa karya lain dalam bidang Islamic Studies, seperti al-Isläm Hal Huwa al-Ḥāl, al-Ṣaum: al-Arkān fí al-Mizān, dll. Tetapi munculnya karya-karya Zakaria ini tidak didampingi dengan keterbukaan biografinya. Seyogyanya sebuah karya ilmiah ketika dijadikan sebuah obyek penelitian, diikut sertakan pula biografi dari si penulis. Ini penting untuk dilakukan agar diketahui latar belakang penulisan karya tersebut, keterpengaruhan yang menjadi karakteristik penulisan, pemikiran penulis, dan sebagainya. Tetapi sampai saat ini penulis belum mengetahui biografi Zakaria Ouzon secara lengkap meski penulis telah mencari biografinya mengguunakan mesin pencari virtual. Ini menyebabkan penulis kesulitan dalam meneliti latar belakang penulisan, metode dan karakteristik penulisan Zakaria Ouzon dalam kitabnya Jināyat al-Bukhāri. ${ }^{9}$

Tetapi penulis menemukan beberapa komentar negatif tentang Zakaria Ouzon. Ini terkait dengan karya-karyanya yang cukup kontroversial. Salah satu tokoh yang memandang negatif Zakaria Ouzon adalah Aiman Ibrahim. Dalam harian al-Mujtama', Aiman menyatakan bahwa Zakaria Ouzon merupakan penulis yang misterius. Aiman menyebut Zakaria Ouzon sebagai penulis 'pengecut' yang takut mempublikasikan dirinya. ${ }^{10}$

Karena kesulitan untuk mengidentifikasi biografi Zakaria Ouzon, maka hanya karya-karyanya saja yang bisa diteliti. Beberapa intelektual Islam yang pernah meneliti karya Zakaria Ouzon adalah para pemikir muslim yang tergabung dalam Islamic Research Academy Cairo (Majma' al-Buhüs al-Islämi). Setelah melakukan penelitian terhadap karya-karya Zakaria Ouzon, Islamic Research Academy Cairo menyatakan bahwa Zakaria Ouzon adalah orang sesat dan meminta agar karya-karyanya dicekal, terutama karyanya yang berjudul Jināyat al-Bukhāri. ${ }^{11}$

Terlepas dari penilaian negatif beberapa komentator di atas, penulis melihat bahwa sosok Zakaria dari segi pemikirannya tidak begitu jauh dari pemikir kontemporer saat ini yang mengedepankan ijtihad dengan akal dalam memahami teksteks keagamaan. Hal ini terlihat pada kalimat sambutan yang Zakaria tulis dalam trilogi Jināyat-nya. Zakaria mengatakan bahwa hasil karyanya ini ditujukan kepada para pemikir yang mendahulukan akalnya dalam memahami teks-teks agama. Zakaria juga tidak menyetujui terhadap sikap umat yang lebih mendahulukan taqlid daripada

\footnotetext{
${ }^{8}$ Zakaria Ouzon menuangkan gagasannya ke dalam beberapa karyanya. Karya Zakaria yang cukup monumental, menurut penulis, adalah kitab trilogi Jināyat, yakni Jināyat al-Sibawaihi, Jināyat alBukhäri, dan Jināyat al-Syäfi'i.

${ }^{9}$ Perlunya mengetahui biografi penulis adalah untuk mengetahui latar belakang pemikiran penulis dan konteks ketika penulisan kitab. Dengan mengetahui hal-hal tersebut diharapkan dapat diketahui 'kunci' makna dari kata-kata yang diungkapakan. Lihat E. Sumaryono, Hermeneutik: Sebuah metode Filsafat, (Yogyakarta: PT Kanisius, 1999), 33.

10 Lihat Hasan Mahfud, Kritik atas Kritik Hadis Zakaria Ouzon terhadap al-Bukhäri (Kajian Hermeneutik), (Yogyakarta: Tesis UIN Sunan Kalijaga, 2013), 27.

${ }^{11}$ Lihat Muhammad Rikza Muqtada, Kritik Nalar Hadis Zakaria Ouzon, (Yogyakarta: Tesis UIN Sunan Kalijaga, 2014), 26.
} 
ijtihad. Selain itu Zakaria kurang menyetujui konsep pengambilan hukum Islam dengan ijmā' dan qiyās. ${ }^{12}$

Tetapi meskipun dalam trilogi kitab Jināyat-nya Zakaria selalu memberikan sambutan yang mengidentifikasikan bahwa dirinya menjunjung tinggi akal dalam melakukan ijtihad, tetapi dalam prakteknya metode yang digunakan Zakaria dalam menguji kualitas hadis tidaklah jauh berbeda dengan metode ulama klasik terdahulu, yakni dengan cara membandingkan hadis yang dicurigai ke-sahịh-annya dengan riwayat-riwayat yang lebih sahịh derajatnya, seperti Alquran, Sunnah yang mutawatir, maupun sejarah. Hal ini menguatkan dugaan bahwa sesungguhnya Zakaria Ouzon memahami kaidah-kaidah penelitian hadis klasik.

\section{Kajian terhadap Kitab Jināyat al-Bukhāri}

Terlepas dari penilaian beberapa intelektual muslim yang menyatakan Zakaria Ouzon adalah orang yang sesat dan kitab-kitabnya tidak diperbolehkan untuk dipelajari, karya-karyanya memang cukup monumental dan kontroversial. Zakaria bisa dibilang cukup berani dalam melancarkan komentar-komentarnya terhadap karya-karya para cendekiawan muslim yang dianggap telah memberikan sumbangsih besar terhadap kajian Islam dan diakui kebenarannya sehingga tidak perlu lagi adanya peninjauan ulang.

Beberapa cendekiawan tersebut adalah Imam Sibawaihi yang merupakan tokoh dalam bidang bahasa. Sebagaimana diketahui bahwa Imam Sibawaihi adalah peletak dasar ilmu tata bahasa Arab yang dikenal dengan sebutan nahwu dan sharaf. Buah pemikiran Imam Sibawaihi ini menjadi karya yang monumental yang hingga saat ini menjadi rujukan utama bagi para pelajar yang menekuni kajian bahasa Arab. Dalam memahami teks-tekas agama, nahwu dan sharaf adalah salah satu alat yang diwajibkan untuk dikuasai. Sebagaimana dalam memahami Alquran yang diperlukan sekitar 15 ilmu yang salah satunya adalah menguasai nahwu dan sharaf. ${ }^{13}$ Disinilah letak pentingnya ilmu bahasa, khususnya nahwu dan sharaf, dalam studi agama.

Meskipun perkembangan kajian bahasa Arab cukup signifikan dengan Imam Sibawaihi sebagai pelopornya, namun Zakaria melihat bahwa perkembangan tersebut tidak bisa terlepas dari apa yang telah dicetuskan oleh Imam Sibawaihi. Menurutnya perkembangan kajian bahasa Arab seharusnya bisa lebih dari sekarang. Karena apa yang ditawarkan oleh Imam Sibawaihi tidak lebih dari sekedar memahami teks dari aspek makna saja. ${ }^{14}$ Sedangkan dalam memahami teks-teks agama, yang notabenenya berbahasa Arab, diperlukan seperangkat ilmu yang cukup kompleks agar dapat

\footnotetext{
${ }^{12}$ Zakaria Ouzon, Jināyat al-Bukhāri: Inqādz al-Dīn min imām al-Muhaddisīn, (Lebanon: Riad el-Rayyes Books, 2004), 9. Lihat juga Jināyat al-Sibawaihi: al-Raf̣ al-Täm li mā fì al-Naḥw min Auhäm dan Zakaria Ouzon, Jināyat al-Syäfi' 'i. Takhlịs al-Ummah min Fiqh al-A'immah.

13 Muhammad bin Muhammad Abu Syahbah, Israilliyat dan Hadis-hadis Palsu Tafsir Alquran, terj. Mujahid Muhayan, dkk, ((Depok: Keira Publishing, 2014), 29.

${ }^{14}$ Zakaria Ouzon, Jināyat al-Sibawaihi: al-Raf̣̣ al-Tām li mā fĩ al-Naḥw min Auhām, (Lebanon: Riad elRayyes Books, 2004), 13-14.
} 
dipahami secara komprehensif, dan ilmu nahwu sharaf sangatlah kurang untuk hal tersebut. ${ }^{15}$

Tokoh cendekiawan selanjutnya yang memberikan sumbangsih besar bagi keilmuan Islam yang menjadi kritik Zakaria, adalah Imam Syafi'i. Beliau dikenal sebagai orang pertama yang meletakkan pondasi penggalian hukum Islam. Pondasi penggalian hukum tersebut didasarkan pada 4 hal, yakni: Alquran, sunnah, ijma' dan qiyas. 4 hal ini diyakini dan disepakati oleh ulama klasik yang konsen dalam bidang hukum Islam. ${ }^{16}$

Dengan metode tersebut Imam Syafi'i dan generasi selanjutnya banyak menghasilkan hukum-hukum Islam yang berguna untuk mengatur kehidupan umat Islam sehari-hari. Hukum-hukum tersebut hingga saat ini masih digunakan oleh mayoritas umat Islam. Hal ini memicu Zakaria untuk mengkritisi sikap umat yang terlalu mengagungkan hasil ijtihad ulama terdahulu yang notabenenya terikat oleh tempat, waktu dan keadaan yang jauh berbeda dengan saat ini. Hasil ijtihad ini, menurut Zakaria, tentulah tidak lagi relevan dengan kondisi saat ini. ${ }^{17}$ Maka perlu adanya rekonstruksi dalam bidang hukum agar relevan dan lebih bisa menjawab persoalan-persoalan umat yang saat ini jauh lebih kompleks.

Zakaria melanjutkan kritiknya terhadap keilmuan Islam yang dianggap mapan dengan mengkritisi kitab Sạhịh al-Bukhāri. Sebagaimana diketahui, dalam bidang hadis, Sạhịh al-Bukhāri menempati urutan pertama dari segi otentisitas hadis. Kitab ini dipercaya, hingga saat ini, menghimpun hadis-hadis yang otentik, sehingga menjadikannya rujukan utama dalam mengkaji hadis-hadis nabi. ${ }^{18}$ Dari aspek hukum, tentunya kitab ini juga menjadi rujukan utama dalam menggali hukum. Karena sebagaimana yang telah penulis terangkan sebelumnya bahwa, ahli hukum klasik menempatkan sunnah sebagai sumber hukum yang kedua setelah Alquran. Tentunya Sahịh al-Bukhäri yang memuat hadis-hadis yang autentik menempati posisi pertama dari berbagai macam kitab hadis dan menempati posisi kedua setelah Alquran dalam perannya sebagai sumber hukum Islam. Bahkan sebagian orang mengklaim bahwa Sahịḥ al-Bukhāri adalah kitab terotentik kedua setelah Alquran. ${ }^{19}$

Pandangan yang "berlebihan" inilah agaknya yang menimbulkan kegelisahan Zakaria. Menurutnya tidak seharusnya Șahịh al-Bukhäri yang menghimpun hadis-hadis nabi tersebut dipandang sebagai sesuatu yang suci, sehingga menafikannya dari berbagai macam interpretasi yang memungkinkannya selalu relevan di setiap zaman. Karena jika hadis dipahami sebagai pesan nabi untuk umat agar dijadikan pedoman

\footnotetext{
${ }^{15}$ Untuk bisa memahami bahasa Alquran diperlukan pemahaman yang luas terhadap kosakata, implikasi dan signifikansi bahasanya dalam bahasa aslinya. Pemahaman terhadap tata bahasa dan retorika Alquran juga termasuk hal yang tidak boleh dilupakan. Pendekatan ini hanyalah untuk memahami Alquran dalam tataran literal saja. Masih diperlukan berbagai macam pendekatan lain untuk bisa mengambil nilai dari Alquran. Lihat Ingrid Matson, Ulumul Qur'an Zaman Kita: Pengantar untuk Memahami Konteks, Kisah dan Sejarah Alquran, terj. Cecep Lukman Yasin, (Jakarta: Zaman, 2013), 270.

${ }^{16}$ Joseph Schacht, The Origins of Muhammadan Jurisprudence, terj. Joko Supomo, (Yogyakarta: Insan Madani, 2010), 3.

17 Zakaria Ouzon, Jināyat al-Syâfi' $\bar{i}$ : Takhlịs al-Ummah min Fiqh al-A'immah, (Lebanon: Riad el-Rayyes Books, 2004), 10.

${ }^{18}$ Indal Abror, Kitab al-Ṣaḥị al-Bukhāri, dalam Studi Kitab Hadis, (Yogyakarta: Teras, 2003), 44.

${ }^{19}$ Ibid. 48.
} 
hidup, maka sudah seharusnya hadis selalu terbuka selalu dipahami dan dimaknai ulang agar selalu relevan dengan setiap kondisi. Dari sinilah Zakaria kemudian melontarkan kritik-kritiknya terhadap Sahịh al-Bukhāri dan untuk menyukseskan misinya tersebut, ia menulis sebuah karya yang berjudul Jināyat al-Bukhāri.

Kitab Jināyat al-Bukhāri ini merupakan kitab yang cukup kontroversial. Kitab ini diterbitkan oleh Riad el-Rayyes Book, Lebanon pada tahun $2004 .{ }^{20} \mathrm{Kitab}$ ini terdiri dari 164 halaman yang, secara garis besar, merupakan kritik Zakaria terhadap kitab Sạhịh Bukhāri. Adapun daftar isi dari kitab tersebut adalah sebagai berikut:
a. Al-Ihda',
b. Al-Muqaddimah
c. Fasl al-Awwal: Zubdat al-Kitāb fî Bidāyatihi
d. Fasl al-Śani: al-Bukhāri wa al-Qur'ān al-Karim
e. Fas̆l al-Salis̀: al-Bukhāri wa al-Rasūl al-Karim
f. Faṣl al-Rābi': al-Bukhāri wa al-Diyānāt al-Ukhrā
g. Fas̆l al-Khāmis: al-Bukhāri wa al-Hukm wa al-Ṣahāābat
h. Faṣl al-Sādis: al-Bukhāri wa al-Mar'ah
i. Fas̆l al-Sābi': al-Bukhāri wa al-Majmū'at Mutanāqaḍāt
j. Faṣl al-Sämin: Bayn al-Mađ̣i wa al-Ḥađ̣ir
k. Al-Khātimah
1. Al-Marāji'
m. Al-Fihris

Keseluruhan bab tersebut berisi hadis-hadis dari kitab Sahị̣̂ Bukhāri yang menurut Zakaria perlu diteliti ulang. Zakaria mengumpulkan hadis-hadis tersebut dan membaginya ke dalam beberapa bab. Kitab ini berisi sekitar 105 hadis yang diambil oleh Zakaria dari kitab Sahịh al-Bukhari. Pemilihan hadis-hadis ini adalah untuk membuktikan keotentikan hadis-hadis tersebut. Karena menurut Zakaria hadis-hadis tersebut tidaklah mencerminkan diri nabi sebagai teladan bagi umatnya. Sebagai contoh hadis-hadis yang secara tekstual terlihat mendiskreditkan posisi perempuan. Dalam kitabnya Zakaria secara khusus membahas tentang hadis-hadis dalam kitab Sahịh Bukhäri yang bias gender. Hadis-hadis ini tentunya tidak sesuai dengan pribadi nabi yang menghormati perempuan dan agama pun memberikan kedudukan yang tinggi terhadap perempuan.

Pribadi nabi yang menghormati perempuan ini merupakan bentuk penentangan terhadap sikap masyarakat Arab pada saat itu yang memandang sebelah mata perempuan dan posisi mereka berada di bawah laki-laki. Jika demikian maka hadishadis yang terlihat secara tekstual mendiskreditkan perempuan tersebut perlu diuji kembali keotentikannya. Penulis, dalam penelitian ini, akan menganalisis bagiamana pandangan Zakaria terhadap hadis yang misoginis. Hadis pertama adalah tentang wanita menjadi sebagian besar penghuni neraka dan keunggulan laki-laki terhadap perempuan. Hadis ini mendapat kritikan keras dari Zakaria karna dipandang bias gender.

${ }^{20}$ Penulis hanya menemukan bukunya dalam versi pdf. 
Untuk menguji otentisitas sebuah hadis, Zakaria memulainya dengan metode kritik redaksi (matn) hadis. Metode ini digunakan Zakaria karena, menurut penulis, metode kritik riwayat (sanad) sampai saat ini belum bisa digunakan untuk membuktikan keotentikan sebuah hadis dan terjadi banyak perdebatan mengenai hal itu. ${ }^{21}$ Zakaria sendiri menolak metode keotentikan hadis berdasarkan kritik riwayat karena metode ini rentan akan kepentingan-kepentingan politik maupun golongan tertentu. Sebagai contoh metode kritik rijāl yang digunakan untuk menilai kualitas seorang rawi bisa berbeda antar golongan. ${ }^{22}$

Berdasarkan hal tersebut, Zakaria, dalam menguji keotentikan sebuah hadis, lebih menekankan pada kritik redaksi (matn) hadis. Karena pada dasarnya inti dari sebuah hadis adalah redaksi (matn) hadis tersebut. Redaksi (matn) hadis inilah yang menjadi sumber hukum dan pedoman bagi umat Islam. Maka tentunya kritik redaksi (matn) hadis ini merupakan poin penting dalam mengkaji keotentikan sebuah hadis.

Untuk menguji keotentikan sebuah hadis berdasarkan redaksinya, Zakaria membandingkan redaksi sebuah hadis dengan Alquran dan hadis-hadis lain yang derajatnya lebih sahịh. Metode ini tentunya tidak asing di kalangan para ahli hadis, karena metode ini juga digunakan oleh mereka dalam menguji keotentikan sebuah hadis. Dengan metode ini Zakaria kemudian mempertanyakan kembali keotentikan hadis-hadis yang bertentangan dengan Alquran maupun sunnah yang lebih sahịh. Hal ini berdasarkan pemahaman Zakaria bahwa Alquran merupakan wahyu dari Allah yang tentunya tidak perlu dipertanyakan lagi keotentikannya. Sedangkan hadis bukanlah termasuk dari wahyu. ${ }^{23}$ Maka hadis-hadis yang bertentangan dengan wahyu tentu perlu dipertanyakan kembali keotentikannya meskipun hadis tersebut terdapat dalam kitab sahịh seperti Sahịḥ Bukhäri dan Sahịḥ Muslim.

Yang menjadi fokus penelitian ini adalah hadis yang menjelaskan tentang mayoritas penghuni neraka adalah perempuan. Hadis ini menerangkan bahwa ada beberapa macam perbedaan antara laki-laki dan perempuan yang menyebabkan lakilaki lebih unggul dari aspek akal dan agamanya daripada perempuan. Hadis ini juga mengklaim bahwa mayoritas penghuni neraka adalah perempuan yang disebabkan oleh seringnya perempuan melaknat dan mengingkari kebaikan suaminya. ${ }^{24}$ Hadis ini diriwayatkan oleh $\mathrm{Abu}$ Sa'id al-Khudri dengan redaksi sebagai berikut:

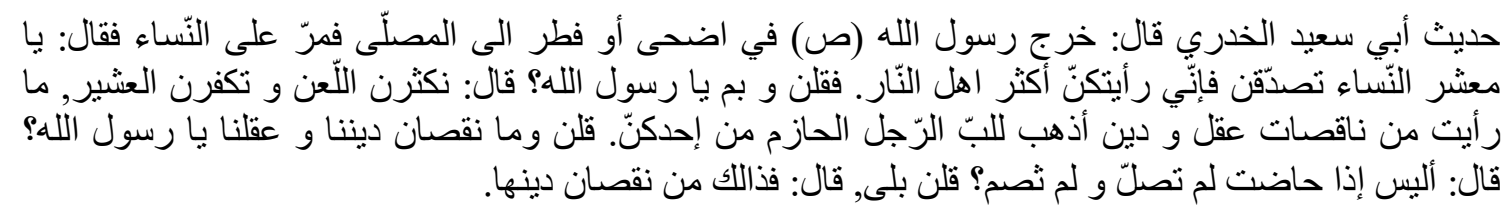

Hadis Abi Sa'id al-Khudri, ia berkata: Rasulullah saw keluar menuju tempat sholat untuk melakukan sholat Fitri atau Adha, kemudian beliau bertemu dengan beberapa perempuan. Maka beliau bersabda: Wahai kaum perempuan, bersedakhlah, karena kau

\footnotetext{
${ }^{21}$ Lihat Kamaruddin Amin, Menguji Kembali Keakuratan Metode kritik Hadis, (Jakarta: Hikmah, 2009), $1-7$.

${ }^{22}$ Ouzon, Jināyat al-Bukhäri, 18.

${ }^{23}$ Zakaria meragukan kewahyuan hadis berdasarkan tiga hal, yakni: Pertama, teks hadis tidak dianjurkan untuk dibaca ketika shalat. Kedua, adanya keraguan tentang keotentikan hadis dikarenakan periwayatannya secara ma'nawi. Ketiga, pelarangan nabi untuk menulis hadis. Ibid., 14-15.

${ }^{24}$ Ibid., 121.
} 
melihat kalian menjadi sebagian besar penghuni neraka. Mereka bertanya: Sebab apa ya Rasulullah? Beliau menjawab: Kalian banyak melaknat dan tidak berterima kasih atas kebaikan suami. Aku tidak mengetahui ada wanita yang kurang akal dan agamanya yang bias menghilangkan akal laki-laki yang sabar, selain salah seorang diantara kamu. Mereka bertanya: Apa kekurangan agama dan akal kami ya Rasulullah? Beliau menjawab: Tidakkah jika perempoua itu haid, dia tidak sholat dan puasa? Mereka menjawab: Iya. Beliau bersabda: Itulah kekurangan agamanya. ${ }^{25}$

Setidaknya ada dua titik poin yang menjadi kritik dari Zakaria terhadap hadis tersebut. Pertama, adalah keunggulan laki-laki dari pada perempuan dari segi agama dan akalnya. Menurutnya hal ini bertentangan dengan ayat Alquran, surat al-Nisā' ayat 34:

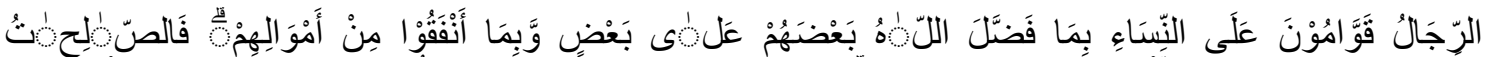

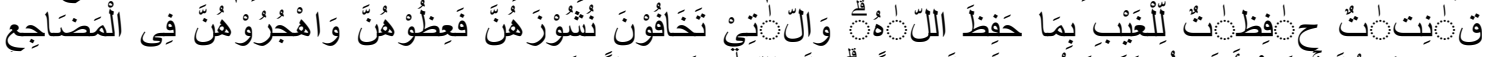

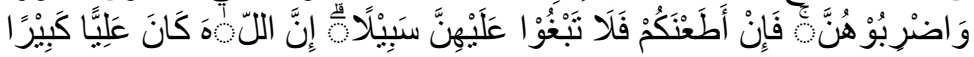
"Kaum laki-laki itu adalah pemimpin bagi kaum wanita, oleh karena Allah telah melebihkan sebagian mereka atas sebahagian yang lain. Maka perempuan-perempuan yang saleh, adalah mereka yang taat (kepada Allah) dan menjaga diri ketika (suaminya) tidak ada, karena Allah telah menjaga (mereka). Perempuan-perempuan yang kamu khawatirkan akan nusyüz, hendaklah kamu beri nasehat kepada mereka, tinggalkanlah mereka di tempat tidur (pisah ranjang), dan (kalau perlu) pukullah mereka. Tetapi jika mereka menaatimu, maka janganlah kamu mencari-cari alasan untuk menyusahkannya. Sungguh, Allah Maha Tinggi, Maha Besar."

Menurut Zakaria terjadi banyak perdebatan mengenai ayat tersebut. hal ini terkait dengan apakah yang diunggulkan oleh Allah itu apakah benar laki-laki atas perempuan. Sedangkan dalam redaksi ayat tersebut tidak dituliskan ba'dihinna, sehingga Zakaria berkeyakinan bahwa ayat tersebut bukanlah menjelaskan tentang keunggulan laki-laki terhadap perempuan. Tetapi menjelaskan keunggulan sebagian keduanya (laki-laki dan perempuan) terhadap sebagian lain (yang juga terdiri dari lakilaki dan perempuan) dari aspek akal, ilmu, perbuatan dan lain sebagainya. ${ }^{26}$

Jika dikaitkan dengan hadis sebelumnya yang menjelaskan tentang keunggulan laki-laki terhadap perempuan dari aspek agama dan akalnya tentu sangat bertentangan dengan ayat ini. Maka keotentikan hadis tersebut perlu dipertanyakan kembali, mengingat hadis tersebut bertentangan dengan ayat Alquran qạt 'i al-wurüd.

Kedua, adalah klaim nabi yang menyatakan bahwa mayoritas penghuni neraka adalah perempuan akibat dari seringnya mereka melaknat dan mengingkari kebaikan suami mereka. Hadis ini bertentangan dengan ayat Alquran, surat al-Nisā' ayat 124:

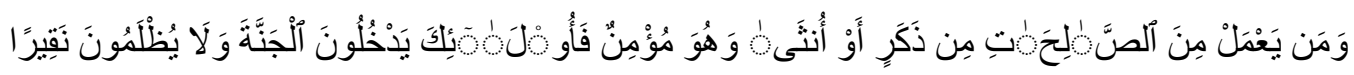

\footnotetext{
${ }^{25}$ Redaksi hadis yang lebih lengkap bisa lihat Sahih al-Bukhari, Kitab al-Haid, Bab Tark al-Hä'id alSaum. Abū 'Abd Allah Muhammd bin Ismā'il al-Bukhāri, Șaḥih al-Bukhari, (Riyadh: Bayt al-Afkār alDauliyyah, 1998), 80.

${ }^{26}$ Ouzon, Jināyat al-Bukhāri, 130.
} 
"Barangsiapa yang mengerjakan amal-amal saleh, baik laki-laki maupun wanita sedang ia orang yang beriman, Maka mereka itu masuk ke dalam surga dan mereka tidak dianiaya walau sedikitpun."

Jika melihat redaksi ayat di atas dapat dipahami bahwa baik laki-laki maupun perempuan yang melakukan amal saleh dan beriman kepada Allah maka mereka akan mendapatkan pahala berupa surga. Dan dapat dipahami pula sebaliknya bahwa yang tidak melakukan hal tersebut akan mendapatkan balasan pula yakni neraka. Sebagaiamana firman Allah dalam surat al-Furqān, ayat 68:

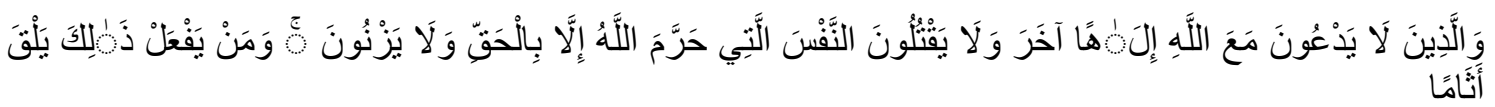

"Dan orang-orang yang tidak menyembah Tuhan yang lain beserta Allah dan tidak membunuh jiwa yang diharamkan Allah (membunuhnya) kecuali dengan (alasan) yang benar, dan tidak berzina, barang siapa yang melakukan yang demikian itu, niscaya Dia mendapat (pembalasan) dosa(nya)."

Tentunya jika seorang istri melaknat dan mengingkari kebaikan suami akan masuk neraka karena tidak melakukan amal saleh, maka sebaliknya juga bila suami melakukan hal tersebut (melaknat dan mengingkari kebaikan istri) akan mendapat dosa dan dimasukkan ke dalam neraka. Hal ini berdasarkan pada surat al-Nisā' ayat 124 yang menjelaskan bahwa baik laki-laki maupun perempuan bisa masuk surga jika melakukan amal saleh dan beriman.

Hadis selanjutnya, yang menjadi fokus penelitian ini, yang mendapat kritik keras Zakaria adalah hadis tentang campur tangan malaikat yang melaknat seorang istri yang enggan untuk di ajak bersenggama oleh suaminya. ${ }^{27}$ Adapun redaksi hadis tersebut adalah sebagai berikut:

$$
\text { حديث ابي هريرة, قال: قال النّبيّ (ص): إذا باتت المر أة مهاجرة فراش زوجها لعنتها الملائكة حنّى نرجع }
$$

"Hadis Abū Hurairah, ia berkata: nabi saw bersabda: Jika seorang istri meninggalkan tempat tidur suaminya, maka malaikat melaknatnya hingga ia kembali." 28

Hadis ini, jelas Zakaria, memberitahukan bahwa malaikat memiliki kuasa untuk melaknat istri yang enggan diajak berhubungan badan dengan suaminya. Lebih lanjut Zakaria menjelaskan bahwa terdapat hadis-hadis lain serupa yang bermakna sama. Keseluruhan hadis tersebut semakin memperkuat argumentasi bahwa wanita serupa dengan hewan ternak yang terkekang keinginannya. ${ }^{29}$ Bagi wanita, yang harus dilakukan adalah menaati setiap perintah suami ketika ia memerintahkan tanpa diperbolehkan untuk menolaknya maupun menggerutu, seperti halnya ajakan untuk berhubungan badan. ${ }^{30}$

Mengenai hadis di atas Zakaria mempertanyakan keotentikannya, karena menurutnya hadis ini terlihat janggal dan tidak masuk akal. Pertama, keterlibatan

\footnotetext{
27 Ibid., 114.

28 Redaksi hadis yang lebih lengkap bisa lihat Șahịh al-Bukhari, Kitäb al-Nikăh, Bä Iżā Bätat alMar'atu Muhäjiratan Firāsy Zaujihā, Bukhari, Șahịh al-Bukhari, 1029.

${ }^{29}$ Ouzon, Jināyat al-Bukhäri, 115.

${ }^{30}$ Ibid. 118.
} 
malaikat terhadap penolakan istri atas permintaan suami. Kedua, hukum seorang suami yang menolak ajakan istri untuk bersenggama. Apakah suami akan mendapatkan hal yang setimpal, yakni laknat dari malaikat, ketika ia menolak istrinya ketika diajak bersenggama. Karena secara tekstual hadis tersebut terlihat mendiskreditkan perempuan yang menolak permintaan senggama suami. Sedangkan teks hadis yang menerangkan sebaliknya tidaklah ditemukan. ${ }^{31}$

Hadis-hadis yang penulis sebutkan di atas adalah hadis-hadis yang menurut Zakaria perlu ditinjau lagi keotentikannya, karena hadis-hadis tersebut tidak mencerminkan pribadi nabi yang menghormati perempuan dan bertentangan dengan ayat-ayat Alquran. Sebenarnya banyak hadis-hadis lain yang terdapat dalam kitab Șahịh Bukhāri yang tidak luput dari kritikan Zakaria. Namun karena keterbatasan penulis maka hanya sebagian kecil saja yang dapat dihadirkan.

\section{Kririk terhadap Jināyat al-Bukhāri karya Zakaria Ouzon.}

Kritik yang dilakukan Zakaria terhadap Șahịh Bukhäri bukanlah sesuatu yang perlu dipandang negatif sebagaimana yang dilakukan oleh beberapa komentator yang penulis sebutkan sebelumnya sehingga mengharuskan adanya pencekalan terhadap karya-karyanya. Menurut pembacaan penulis, bahwa apa yang disampaikan oleh Zakaria bukanlah untuk menghakimi perbuatan Imam Bukhāri yang sengaja berbuat "kriminal" dengan memasukkan hadis-hadis yang tidak otentik ke dalam sahịh-nya, tetapi yang menjadi kritik Zakaria adalah sikap umat yang terlalu menganggap sakral hadis-hadis yang terdapat dalam Sạhịh Bukhäri tanpa melakukan peninjauan dan reinterpretasi terhadapnya. Hal ini tercermin pada kalimat yang Zakaria sampaikan di dalam kitabnya. ${ }^{32}$

Karena jika dilihat dari judul kitab Șậ̣̆h Bukhäri maka tampak jelas bahwa kitab tersebut menghimpun hadis-hadis yang sahịh dari segi sanadnya. ${ }^{33}$ Maka dari aspek matn tentu perlu dikaji kembali agar dapat dipahami secara komprehensif. Semangat reinterpretasi teks ini pada dasarnya sudah dilakukan oleh banyak intelektual muslim lainnya. Interpretasi teks agar lebih sesuai dengan kondisi dan situasi kekinian memang sebuah keniscayaan yang tidak bisa dihindari, mengingat bahwa teks agama, baik Alquran dan hadis, adalah pedoman umat Islam yang sălih li kulli zamān.

Pembacaan singkat yang dapat penulis simpulkan dalam membaca kitab Jināyat al-Bukhäri karya Zakaria ini adalah bahwa tidak ada metode baru yang ditawarkan oleh Zakaria dalam mengintepretasi teks hadis. Apa yang digagas oleh Zakaria dalam kitabnya adalah metode kritik matn hadis yang tentunya tidak jauh berbeda dengan metode kritik matn hadis ulama klasik.

Sebagai contoh metode kritik matn hadis dengan membandingkannya dengan teks-teks lain yang lebih sahịh seperti Alquran atau hadis yang mutawatir. Metode ini

\footnotetext{
${ }^{31}$ Ouzon, Jināyat al-Bukhāri,

32 Muhammad Rikza Muqtada, Kritik Nalar Hadis Zakaria Ouzon, (Yogyakarta: Tesis UIN Sunan Kalijaga, 2014), 30.

${ }^{33}$ Nama kitab Ṣaḥịh Bukhāri adalah al-Jāmi' al-Ṣaḥị al-Musnad min Hadis Rasulillah Ṣallaallahu 'alaihi wa sallam wa Sunanihi wa Ayyāmihi.
} 
agaknya sama dengan apa yang ditawarkan oleh Șalaḥ al-Dīn al-Ạ̣labỉ dalam menguji kualitas hadis dari aspek matn-nya. ${ }^{34}$ Bahkan apa yang ditawarkan oleh Ṣalah al-Dìn alAḍlabỉ dalam menguji kualitas hadis terbilang lebih kompleks daripada Zakaria karena Șalạ al-Dīn al-Aḍlabì mengharuskan adanya Naqd al-Khäriji (kritik sanad) sebelum menguji kualitas hadis dari aspek matn-nya.

Yang menjadi kritik penulis dari kitab Jināyat al-Bukhāri adalah penolakan Zakaria terhadap hadis-hadis yang terdapat dalam kitab Sahịh Bukhāri yang menurut penulis terlalu berlebihan. Karena jika hadis yang tidak sesuai dengan Alquran dan atau sunnah yang lebih tinggi derajatnya ditolak keberadaanya, maka akan mereduksi jumlah hadis-hadist nabi dan semakin lama hadis akan semakin sedikit jumlahnya. Jika hal ini dibiarkan maka posisi hadis nantinya akan tergeser dan hilang.

Reinterpretasi terhadap hadis bukanlah untuk menolak keotentikannya, tetapi untuk memberikan pemahaman baru terhadap sebuah hadis agar lebih relevan di setiap waktu dan tempat. Nabi ketika menyampaikan pesan kepada umatnya tidaklah terlepas oleh waktu dan tempat. Maka yang perlu dipahami adalah bagaimana situasi dan kondisi ketika hadis itu muncul. Penelitian hadis dari aspek sejarah memiliki peran penting dalam hal ini agar dapat dipahami ideal moral yang menjadi inti dari hadis tersebut. ${ }^{35}$ Ketika dapat dipahami ideal moral dari hadis tersebut, lantas ideal moral tersebut diterapkan dalam kehidupan saat ini. Sehingga apa yang terjadi adalah pemahaman ulang terhadap teks dengan tanpa menolak atau menghapus teks tersebut.

Tetapi hadis-hadis nabi tersebut yang tentunya tidak bisa terlepas dari tempat dan waktu serta situasi dan kondisi tertentu adakalanya tidak bisa diaplikasikan dalam tempat, waktu, situasi dan kondisi yang berbeda pula. Hal ini disebabkan berkembangnya kebudayaan manusia yang jauh lebih maju dari pada semasa nabi waktu hidup. Maka hadis-hadis ini pun bersifat universal, temporal dan lokal. ${ }^{36}$ Untuk dapat memahami sifat-sifat hadis tersebut tentunya memerlukan banyak sekali keilmuan dari bidang sejarah, asbāb al-wurūd, dan bagaimana peran nabi ketika menyampaikan hadis tersebut. ${ }^{37}$

\section{Penutup}

Kritik Zakaria Ouzon atas Imam Bukhāri pada hakikatnya bukan untuk menjustifikasi Imam Bukhāri sebagai "kriminal" yang memasukkan hadis-hadis palsu dalam kitabnya. Tetapi yang menjadi kritik Zakaria adalah sikap generasi selanjutnya yang terlalu mensakralkan kitab Șạị̣h Bukhāri sehingga menafikannya dari reinterpretasi. Menurut Zakaria pemahaman terhadap teks agama bukanlah hal yang patut disakralkan, karena hasil pemahaman tersebut terikat oleh waktu dan tempat. Sehingga teks agama memungkinkan untuk dipahami ulang agar relevan dengan situasi dan kondisi kekinian. Dalam kitabnya Jināyat al-Bukhāri, Zakaria banyak mengkritisi dan menolak hadis-hadis yang terhimpun dalam kitab Sạhị̣ Bukhāri karena tidak

\footnotetext{
${ }^{34}$ Ṣalaḥ al-Dỉn Ahmad al-Aḍlabi, Metodologi Kritik Matan Hadis, terj. (Tangerang: Gaya Media Pratama, 2004), 210.

35 Fazlurrahman, Islam dan Modernitas: tentang Transformasi Intelektual, terj. Ahsin Mohammad, (Bandung: Pustaka, 1985), 7.

${ }^{36}$ Syuhudi Ismail, Hadis Nabi yang Tekstual dan Kontekstual, (Jakarta: Bulan Bintang, 1994), 3-4.

${ }^{37}$ Ibid., 4.
} 
sesuai dengan Alquran dan pribadi nabi Muhammad. Hadis-hadis yang semacam inilah yang perlu untuk di-reinterpretasi agar didapatkan makna baru dalam memahami matn hadis. Dengan adanya reinterpretasi, matn hadis tidak stagnan dan selalu berkembang seiring dengan waktyu. Zakaria Ouzon dalam menguji keotentikan hadis-hadis yang terdapat dalam kitab Șạhịh Bukhāri menggunakan metode perbandingan teks hadis dengan Alquran dan sunnah lain yang lebih sahịh. Metode ini bukanlah hal baru yang ditawarkan oleh Zakaria, mengingat metode ini juga digunakan oleh ulama hadis klasik dalam menguji keotentikan matn hadis. Metode interpretasi matn hadis Zakaria, menurut pembacaan singkat penulis, kurang begitu ditunjukkan dalam tulisannya. Zakaria juga terlalu terburu-buru untuk menolak keotentikan hadis yang terhimpun dalam kitab Șahịh Bukhäri, karena jika hal ini dilakukan maka hadis-hadis nabi akan tereduksi jumlahnya dan menjadi lebih sedikit. Sedangkan permasalahan umat semakin lama semakin kompleks dan hadis nabi yang menjadi pedoman hidup umat manusia tidak seharusnya ditolak dan dikurangi jumlahnya, karena ada kemungkinan hadishadis tersebut masih bisa dimaknai ulang agar bisa menjawab problem-problem kekinian.

\section{Daftar Pustaka}

Ạ̣labī, Șalạ al-Dīn Ạ̣mad al. Metodologi Kritik Matan Hadis. terj. (Tangerang: Gaya Media Pratama. 2004).

Amin, Kamaruddin. Menguji Kembali Keakuratan Metode kritik Hadis. (Jakarta: Hikmah. 2009).

Dosen Tafsir Hadis Fakultas Ushuluddin IAIN Sunan Kalijaga Yogyakarta. Studi Kitab Hadis. (Yogyakarta: Teras. 2003).

Fazlurrahman. Islam dan Modernitas: tentang Transformasi Intelektual. terj. Ahsin Mohammad. (Bandung: Pustaka. 1985).

Ismail, Syuhudi. Hadis Nabi yang Tekstual dan Kontekstual. (Jakarta: Bulan Bintang. 1994).

Mahfud, Lihat Hasan. Kritik atas Kritik Hadis Zakaria Ouzon terhadap al-Bukhāri (Kajian Hermeneutik). (Yogyakarta: Tesis UIN Sunan Kalijaga. 2013).

Matson, Ingrid. Ulumul Qur'an Zaman Kita: Pengantar untuk Memahami Konteks, Kisah dan Sejarah Alquran. terj. Cecep Lukman Yasin. (Jakarta: Zaman. 2013).

Muqtada, Muhammad Rikza. Kritik Nalar Hadis Zakaria Ouzon. (Yogyakarta: Tesis UIN Sunan Kalijaga. 2014).

Ouzon, Zakaria. Jināyat al-Bukhāri: Inqādz al-Dīn min Imām al-Mụaddisisin. (Lebanon: Riad el-Rayyes Books. 2004).

, Jināyat al-Sibawaihi: al-Raf̣ al-Tām li mā fî̀ al-Naḥw min Auhām. (Lebanon: Riad el-Rayyes Books. 2004).

, Jināyat al-Syāfi ’’i: Takhtịs al-Ummah min Fiqh al-A'immah. (Lebanon: Riad el-Rayyes Books. 2004).

Schacht, Joseph. The Origins of Muhammadan Jurisprudence. terj. Joko Supomo. (Yogyakarta: Insan Madan. 2010).

Siba'i, al Musthafa. al-Hadis sebagai Sumber Hukum: Kedudukan al-Sunnah dalam Pembinaan Hukum Islam. terj. Dja'far Abd. Muhith. (Bandung: Diponegoro. 1993). 
Sumaryono, E. Hermeneutik: Sebuah metode Filsafat. (Yogyakarta: PT Kanisius. 1999).

Syahbah, Muhammad bin Muhammad Abu. Israilliyat dan Hadis-hadis Palsu Tafsir Alquran. terj. Mujahid Muhayan. dkk. ((Depok: Keira Publishing. 2014). 